\title{
塩蔵漬菜中フェオホーバイド $\mathrm{a}$ の白ネズミに対する 光力学的作用について
}

\author{
山田幸二 \\ 郡山女子大学家政学部食物栄盖学科
}

\author{
Photodynamic Action of Pheophorbide a in Pickeled \\ Green on Rats \\ Koji YAMADA \\ Food and Nutrition Laboratory, Faculty of the Science of Living, Koriyama \\ Women's College, Koriyama, Fukushima
}

In order to elucidate the mechanism of photodynamic action of pheophorbide $a$ in the salted Takana on rats, photosensitized degradation of amino acids and fatty acids were studied in comparison with that of rose bengale.

A $10 \mathrm{mg} / \mathrm{rat}$ dose of pheophorbide a or rose bengale was injected intraperitoneally into rats, and after being kept in dark place for $15 \mathrm{hr}$ they were irradiated under a light intensity of $20,000 \mathrm{lux}$. The pheophorbide a injected rats died within $45 \mathrm{~min}$. On the contrary the rose bengale injected rats were alive even after the irradiation for $8 \mathrm{hr}$. But subsequent feeding for one week in the dark caused loss of hair and necrosis of skin.

Amino acids mixture solutions containing pheophorbide a or rose bengale were irradiated for $8 \mathrm{hr}$. Consequently, rose bengale caused photodynamic degradation of histidine, methionine, cystine and tyrosine, whereas pheophorbide a did not have such effects. Also, fatty acids solutions containing pheophorbide a were irradiated for $3 \mathrm{hr}$ or $5 \mathrm{hr}$, and it was found that unsaturated fatty acids were broken down.

(Received March 11, 1974)

塩蔵漬菜（野沢菜漬，タカ菜漬）を白ネズミに投与し 可視光線を照射して飼育すると成長阻害, 死亡, 背部の 脱毛, 耳や背部のネクローゼ等の食慨性の光過敏症がみ られ，これらの原因は塩蔵漬菜中フェオホーパド a が 増感剤となって起こる光力学的作用によることを著者ら はすでに報告した1。

光増感作用を有する物質の溶血作用 ${ }^{233)}$ ，抗菌作用 ${ }^{435)}$, 酵素の失活 ${ }^{(2) 7)}$, アミ八酸の光酸化等 ${ }^{7) ~ 10)}$ について多く 報告されている。これらはいずれるキサンテン系色素, チフジン系色素, アクリジン系色素等についての報告で ある。

本研究は塩蔵漬菜中フェオホーパイドaが增感剤とな って起こる白ネズミの光過敏症の機構を明らかにするた め,フェオホーパイド、による白ネズミの光毒性, アミ ノ酸, 脂肪酸の光分解に及ぼす影響についてローズペン ガルと対比して検討したので報告する。

\section{実 験 方 法}

\section{1. 供試品}

実験に使用したフェオホーパイド $\mathrm{a} は$ は，タカ菜（12月 に収檴）を $10 \%$ 食塩で 2 カ月間漬込んだのち，室内で 乾燥, 粉末として, 先に報告した方法”, 寸なわち、エ 一テル-酢酸 $(5: 1 \mathrm{v} / \mathrm{v})$ 混液で色素を抽出, 水洗法でェ 一テル層を分離, ついで数回水洗し, 濃度の異なる塩酸 で分画， $15 \%$ 塩酸区分を分離し，その塩酸区分をエーテ ルで洗浄したあと，クロロホルムで色素を抽出し，その クロロホルム層を数回水洗し、ロータリーエバポレータ 一で蒸発漧固し結晶とした。この物質はフェオホーバィ ド a 以外に若干のフェオホーバイドbを確認したが，エ ーテル溶液の吸収スペクトル (Fig. 1) は $410 \mathrm{~m} \mu, 505$ $\mathrm{m} \mu, 535 \mathrm{~m} \mu, 607 \mathrm{~m} \mu, 665 \mathrm{~m} \mu$ に吸収ピークがみられ,

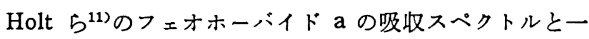
致したので完全な単一物質ではないがフェオホーバイド a とした。

この物質は脂溶性であるため, 使用の際, $\mathrm{pH} 10$ の 


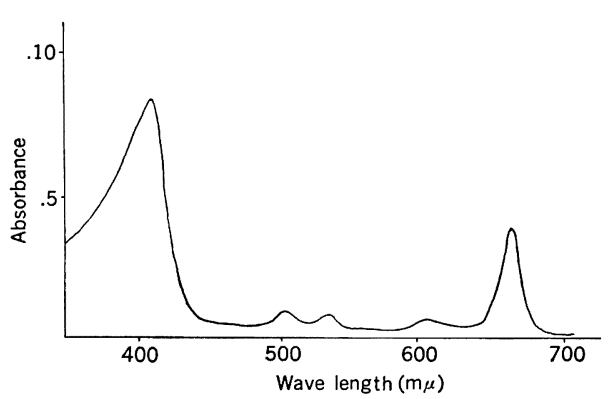

Fig. 1. Absorption spectra of pheophorbide $a$ in ether.

$0.067 \mathrm{M}$ りん酸緩衝液，アセトンまたはクロロホルムに 溶かした。

フェオホーバイド $\mathrm{a}$ と対比のためのローズベンガル は, 食品添加物としての市販品 (三栄化学製)を $\mathrm{pH} 10$ の $0.067 \mathrm{M}$ りん酸緩衝液，またはアセトンに溶かして 使用した。

2. 白ネズミに対するフェオホーパイド $\mathrm{a} ，$ ローズヘ ンガルの光力学的作用

体重 72 84 g の吞竜系雄白ネズミに光照射前日の午 後 5 時に 1 頭当たり $10 \mathrm{mg} / \mathrm{ml}$ のフェオホーバイド a, またはローズベンガルのりん酸緩衝液 $(\mathrm{pH} \mathrm{10)} 1 \mathrm{~m} l$ を 腹腔内投与し, 翌日の午前 8 時まで, 恒温恒湿（温度 $23{ }^{\circ} \mathrm{C}$, 湿度 $50 \%$ ）の暗い部屋で飼育したのち, 先に報告 した装置, すなわち, 光源としてタングステンランプ （日立の屋内反射型， $100 \mathrm{~V} ， 200 \mathrm{~W}$ ）を用い, 20,000 ル ックスの照度で 8 時間照射し観察した。なお，コントロ ールはりん酸綏衙液（pH 10）のみを腹腔内に投与し試 験群と同じ条件で行なった。

\section{3. アミノ酸の光分解}

17 種のアミノ酸（田辺必須アミノ酸研究基金）をトリ ス緩衙液 ( $\mathrm{pH}$ 9) で $0.002 \mathrm{mmole} / \mathrm{ml}$ の溶液を作成し, その $9.5 \mathrm{ml}$ とフェオホーバイド a，またはローズペン ガルのりん酸緩衝液 $(2.0 \mathrm{mg} / \mathrm{ml}) 0.5 \mathrm{ml}$ を 2 本の試験 管 $(18 \times 180 \mathrm{~mm})$ にとり, 一方を静置, もう1本の試 験管はアスピレーターを用い通気し，照度 20,000 ルッ クスで 8 時間照射したのち, 純水で希釈し, 残存フミ, 酸をアミノ酸自動分析機（柳本製作所製 LC-51 A 型） で分析しアアミノ酸の分解度をみた。

\section{4. 脂肪酸の光分解}

脂肪酸の光分解にはリノール酸（和光純薬製で $\mathrm{C}_{16: 0}$, $\mathrm{C}_{18: 1}$ が若干検出), ステアリン酸（半井化学製で $\mathrm{C}_{14: 0}$, $\mathrm{C}_{16: 0}, \mathrm{C}_{18: 0}$ の混合物であるため, 以後飽和脂肪酸と記 す), 大豆油脂肪酸, アマニ油脂肪酸（いずれる日清製 油製）を用いた。
フェオホーバイド、とローズベンガルとの比較実験は リノール酸のフセトン溶液 $(0.6 \mathrm{mg} / \mathrm{ml}) 9.5 \mathrm{ml}$ とフェオ ホーバイドaまたはローズベンガルのアセトン溶液 $(2.0$ $\mathrm{mg} / \mathrm{m} l) 0.5 \mathrm{~m} l$ を秤量瓶 $(30 \times 30 \mathrm{~mm})$ にとり, 照度 20,000 ルックスに調製したタンクスステンンプで一定 時間照射した。その他の実験は溶媒としてクロロホルム を使用し, 飽和脂肪酸は $0.6 \mathrm{mg} / \mathrm{ml}$, 大豆油脂肪酸, アマニ油脂肪酸はいずれる $2.0 \mathrm{mg} / \mathrm{ml}$ の溶液とし，そ の $9.5 \mathrm{ml}$ とフェオホーバイド a クロロホルム溶液 $(2.0$ $\mathrm{mg} / \mathrm{m} l) 0.5 \mathrm{~m} l$ を秤量瓶にとり, リノール酸の場合と 同じ条件で行なった。

脂肪酸の分解は脂肪酸のガスクロマトグラムより判定 した。すなわち, 光照射を行なったあと, 溶媒を除き， さらに塩酸メタノールでメチル化したあと, 柳本製作所 製 $\mathrm{G} 8$ 型ガスクロマトグラフィーを用いて脂肪酸組成を 調べた。ガスクロマトグラフィーの条件はキャリアガス に He を使用し, 流速 $15 \sim 20 \mathrm{ml} / \mathrm{min}$, カラム温度 180 ${ }^{\circ} \mathrm{C}$, 注入口温度 $250^{\circ} \mathrm{C}$, カラム内径 $4 \mathrm{~mm}$, 長さ 2.25 m のステンレスカラムで, 充てん剂には 15\% DEGS を用い, 水素炎イオン化検出器で測定した。

\section{実験結果括よび考察}

\section{1. フェオホーバイド $\mathrm{a} ，$ ローズベンガルの白ネズミ に対する光力学的作用}

フェオホーパイド a，ローズベンガルを腹腔内に投与 し，光を照射した結果を Table 1 に示した。りん酸緩 衝液のみを投与した群 (control) は光照射中, 照射後い ずれも異常現象はみられないがフフェオホーバイド、投 与群は前報1) と同じように光照射と同時に耳が紅斑し, かゆみを訴穴，4５分後には籠の中を激しく動き始 め, その後, 両後肢が麻疩症状を呈し, ついで歩行困難, 呼吸困難となり，35 45 分後に死亡した。死亡した白 ネズミを剖見した結果，投与したフェオホーバイド、は 肉眼でも観察できるほどの大きな粒子となり胃の下に蓄 積がみらた。おそらく，血中に入る前にこのような部 位に蓄積されたあと, 徐々に血中に放出されているるの と考えられる。ローズペンガル投与群は 8 時間光を照射 したが，照射中には異常は認められなかった。その後 1 週間暗所で飼育した結果, 後遺症として背部, すなわち 良く光の当たった部分の脱毛が起こり,さらに脱毛した 部分に壊死症状が観察された。

フェオホーバイド a の光力学的作用は強力な致死効果 をもたらし, また先に報告したように野沢菜漬, タカ菜 漬を投与し, 光を照射して起こる現象として死亡, 耳の 壊死, ついで背部の脱毛, ネクローゼ等が起こるのに対 し, ローズベンガルは背部の眖毛, 壊死のみで死亡, 耳 の異常現象などはみられないことから、フェオホーパイ 
Table 1. Effects of pheophorbide a and rose bengale on photosensitization in rats.

\begin{tabular}{|c|c|c|c|c|c|c|}
\hline \multirow{2}{*}{ Group } & \multirow{2}{*}{ Body wt. } & \multirow{2}{*}{ Dose/rat } & \multicolumn{2}{|c|}{ During irradiation } & \multicolumn{2}{|c|}{ After irradiatian } \\
\hline & & & Pruritus & Death (min) & Loss of hair & Necrosis of skins \\
\hline \multirow{3}{*}{ Control } & $79 \mathrm{~g}$ & $0 \mathrm{mg}$ & - & - & - & - \\
\hline & 75 & 0 & - & - & - & - \\
\hline & 78 & 0 & - & - & - & - \\
\hline \multirow{3}{*}{ Pheophorbide a } & 82 & 10 & + & $+(35)$ & & \\
\hline & 77 & 10 & + & $+(45)$ & & \\
\hline & 78 & 10 & + & $+(45)$ & & \\
\hline \multirow{3}{*}{ Rose bengale } & 80 & 10 & - & - & + & + \\
\hline & 84 & 10 & - & - & + & + \\
\hline & 72 & 10 & - & - & + & + \\
\hline
\end{tabular}

A $10 \mathrm{mg} /$ rat dose of pheophorbide a or rose bengale was injected intraperitoneally into rats, and after being kept in a dark place for $15 \mathrm{hr}$ they were irradiated under light intensity of 20,000 lux.

Results: + active, - negative.

ド a とローズベンガルの光力学的作用は異なるすのと推 定される。

\section{2. フェオホーバイド a あるいはローズベンガル存在} 下アミノ酸に及ぼす光の影響

フェオホーバイド a とローズペンガルによるアミノ酸 の光分解の結果を対照区 (control) の残存 アミノ酸を 100 とし，おのおのを Table 2, 3 に示した。アミノ酸 溶液にローズペンガルを添加し，光を照射するとヒスチ シン, メチオニン, シスチン, チロシンの分解がみら れ, とくにヒスチジン, チロシンの分解が大であった。 またこれらアミノ酸の分解は, 静置 (Table 2) して光照 射するよりる通気したほう (Table 3) が分解は著しいこ とから,これらの分解反応は好気的な反応であり,すで に報告されている結果7) と一致する。一方，フェオホー ハイド a 添加と光照射によるアミノ酸の分解は, 静置, 通気いずれの条件に拈いてもみられないことから,フェ オホーハイド、はアミノ酸の光分解能がみられない。

橋本 $^{12)}$, Clare (13) $^{13}$ 光過敏症の機構について, 光力 学的物質は可視光線下にさらされると一定の光ェネルギ 一を吸収して活性化し，第二の物質に出合うとこれにェ ネルギーを移し，このエネルギーを受けた物質は酸素が あると酸化される。この場合酸化を受けるのはたん白質 で, その構成アミノ酸であるヒスチジン,トリプトファ ン, チロシンの酸化によって起こる現象であるとしてい る。したがってローズベンガルによる光過敏症の機棈 は,アミノ酸のモデル実験より生体のアミノ酸の分解と の関連性は大であると推察されるが, フェオホーハイド aによる光過敏症はローズペンガルによる脱毛や組織
（とくに皮層）の壊死現象と異なって, 短時間に両後肢 の麻痷, 呼吸困難等を呈し, ただちに死亡すること, ア ミノ酸の光分解がみられないことなどから，フェオホー バィド a の光力学的作用とローズベンガルの光力学的作 用は異なるものと推察される。

3. フェオホーバイドaあるはローズベンガル存在 下脂肪酸に及ぼす光の影響

リノール酸のアセトン溶液にローズペンガル，または フェオホーハイイド、を添加し，5時間光照射した結果を Fig. 2 にガスクロマトグラフムで示した。その結果, 口 一ズベンガル添加と対照 (blank) との差はみられないが フェオホーパイド a添加によってリノール酸（以後ガス クロマトグラム上の脂肪酸は炭素の数と二重結合の数で 記す）のピークが著しく小さくなり，溶媒近くに $\mathrm{C}_{18: 2}$ の分解物と思われる多くの新しいピークがチャート上に 検出された。

飽和脂肪酸 $\left(\mathrm{C}_{14: 0}, \mathrm{C}_{16: 0}, \mathrm{C}_{18: 0}\right.$ の混合物), リノール 酸の多い大豆油脂肪酸, リノレン酸の多いフマ二油脂肪 酸のクロロホルム溶液にフェオホーバイド、を添加し， 光照射した結果を Fig. 3, Fig. 4, Fig. 5 に各ガスクロ マトクラムで示した。

飽和脂肪酸はフェオホーハイド a の存在下で光を照射 しても, ほとんと対照と同じガスクロマトグラムを示し たが, 大豆油脂肪酸, アマニ油脂肪酸にフェオホーバィ ド、を添加して, 5 時間光を照射すると $\mathrm{C}_{18: 1}, \mathrm{C}_{18: 2}$, $\mathrm{C}_{18: 3}$ のピークが著しく小さくなり, $\mathrm{C}_{16: 0}$ または $\mathrm{C}_{16: 0}$ 以前に不飽和脂肪酸の分解物と思われる新しいピークが チャート上に多く検出された。なお，脂肪酸溶液のみに 
Table 2. The effect of visible light on amino acids in the presence of pheophorbide a or rose bengale.

\begin{tabular}{cccc}
\hline \hline Amino acids & Control & Pheophorbide a & Rose bengale \\
\hline Lys & 100 & 93 & 94 \\
His & 100 & 100 & 63 \\
Arg & 100 & 101 & 93 \\
Asp & 100 & 115 & 102 \\
Thr & 100 & 98 & 94 \\
Ser & 100 & 113 & 107 \\
Glu & 100 & 114 & 99 \\
Pro & 100 & 99 & 102 \\
Gly & 100 & 110 & 93 \\
Ala & 100 & 89 & 113 \\
Cys & 100 & 118 & 92 \\
Val & 100 & 98 & 115 \\
Met & 100 & 93 & 65 \\
Ile & 100 & 113 & 105 \\
Leu & 100 & 110 & 99 \\
Tyr & 100 & 107 & 74 \\
Phe & 100 & 101 & 93 \\
\hline \hline
\end{tabular}

To $9.5 \mathrm{~m} l$ of Tris-buffer $(\mathrm{pH} 9)$ containing $0.002 \mathrm{mmole} / \mathrm{m} l$ of the amino acids was added $0.5 \mathrm{~m} l$ of phosphate buffer ( $\mathrm{pH} \mathrm{10}$ ) containing $2.0 \mathrm{mg} / \mathrm{ml}$ of the pheophorbide a or rose bengale and irradiated for $8 \mathrm{hr}$. Control system contained $0.5 \mathrm{~m} l$ of phosphate buffer $(\mathrm{pH} 10)$ instead of $0.5 \mathrm{~m} l$ pheophorbide a or rose bengale. Each amino acid is showed as percentage of the sample against that of the control.

Table 3. The effect of visible light on amino acids in the presence of pheophorbide a or rose bengale.

\begin{tabular}{cccc}
\hline \hline Amino acids & Control & Pheophorbide a & Rose bengale \\
\hline Lys & 100 & 102 & 101 \\
His & 100 & 94 & 0 \\
Ahg & 100 & 101 & 107 \\
Asp & 100 & 99 & 102 \\
The & 100 & 97 & 96 \\
Ser & 100 & 102 & 99 \\
Glu & 100 & 99 & 97 \\
Pro & 100 & 109 & 110 \\
Gly & 100 & 105 & 103 \\
Ala & 100 & 95 & 92 \\
Cys & 99 & 74 \\
Val & 100 & 96 & 88 \\
Met & 100 & 98 & 7 \\
Ile & 100 & 96 & 95 \\
Leu & 100 & 98 & 97 \\
Tyr & 100 & 99 & 17 \\
Phe & 100 & 93 & 104 \\
\hline \hline
\end{tabular}

A reaction mixture was the same as Table 2. The mixture were irradiated in air for $8 \mathrm{hr}$. Each amino acid is the same as Table 2 . 

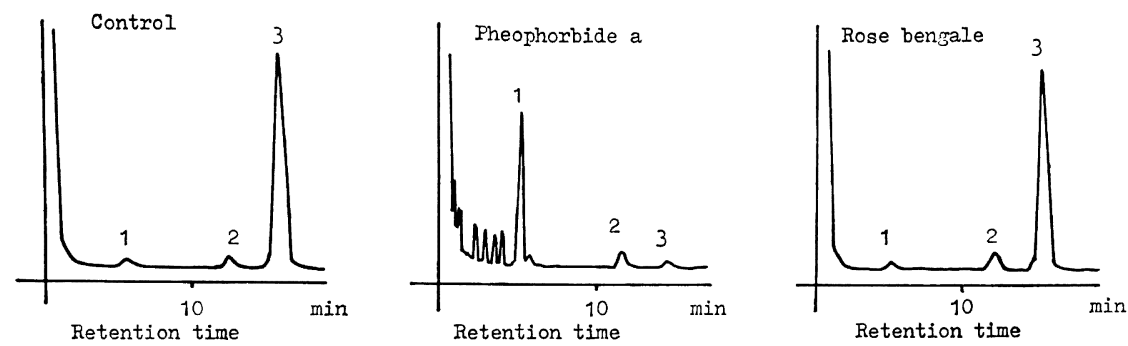

Fig. 2. Changes in the gas chromatograms of linoleic acid produced by the photodynamic action of pheophorbide a or rose bengale.

$9.5 \mathrm{ml}$ of chloroform solution containing $0.6 \mathrm{mg} / \mathrm{ml}$ of the linoleic acid was mixed $0.5 \mathrm{~m} l$ of chloroform solution containing $0.2 \mathrm{mg} / \mathrm{ml}$ of the pheophorbide a or rose bengale, and irradiated for $5 \mathrm{hr}$. Control system contianed $0.5 \mathrm{ml}$ of chloroform instead of $0.5 \mathrm{ml}$ chloroform solution of pheophorbide a or rose bengale.

$1=\mathrm{C}_{16: 0}, 2=\mathrm{C}_{18: 1}, 3=\mathrm{C}_{18: 3}$.
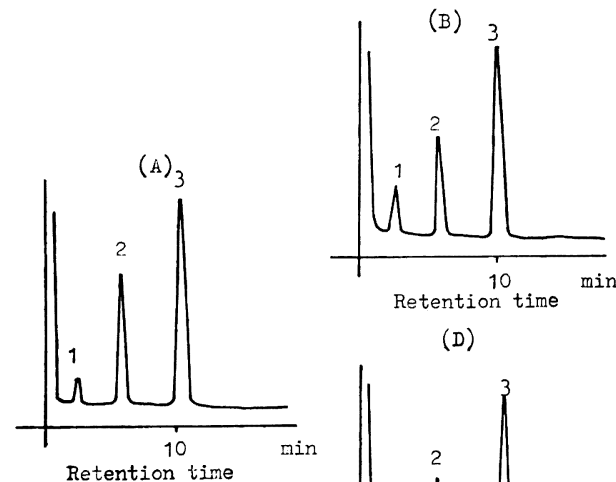

(D)

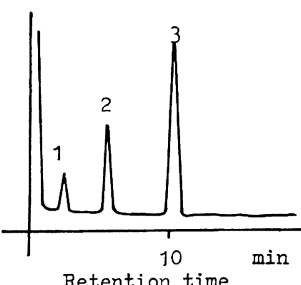

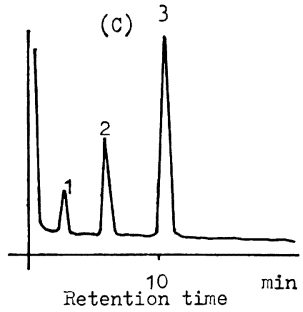

(E) 3

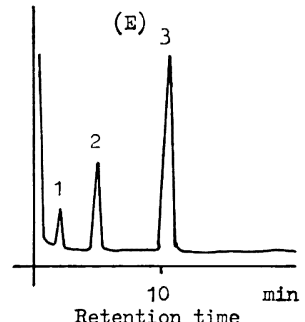

Fig. 3. Changes in the gas chromatograms of saturated fatty acids produced by the photodynamic action of pheophorbide a.

$9.5 \mathrm{~m} l$ of chloroform solution containing $0.6 \mathrm{mg} / \mathrm{ml}$ of the saturated fatty acids was mixed $0.5 \mathrm{~m} l$ of chloroform solution containing $0.2 \mathrm{mg} / \mathrm{ml}$ of the pheophorbide a, and irradiated under light intensity of 20,000 lux. Control system contained $0.5 \mathrm{ml}$ of chloroform instead $0.5 \mathrm{~m} l$ chloroform solution of pheophorbide a.

(A) control, irradiation time was $0 \mathrm{hr}$, (B) control, irradiation time was $3 \mathrm{hr}$, (C) control, irradiation time was $5 \mathrm{hr}$, (D) with pheophorbide a, irradiation time was $3 \mathrm{hr}$, (E) with pheophorbide a, irradiation time was $5 \mathrm{hr}$.

$1=\mathrm{C}_{14: 0}, 2=\mathrm{C}_{16: 0}, 3=\mathrm{C}_{18: 0}$. 
(B)

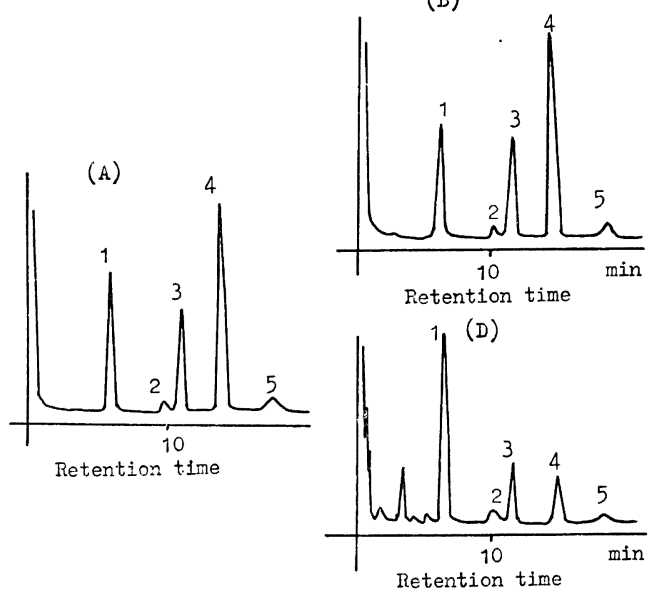

(c)

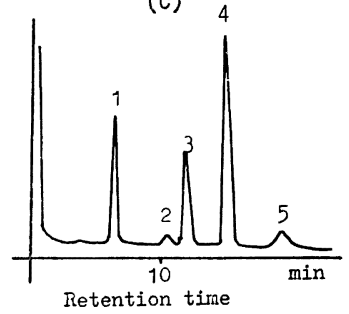

$(E)$

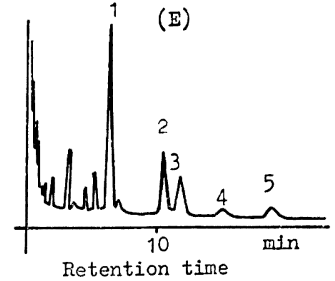

Fig. 4. Changes in the gas chromatograms of soybean oil fatty acids produced by the photodynamic action of pheophorbide a.

$9.5 \mathrm{~m} l$ of chloroform solution containing $2.0 \mathrm{mg} / \mathrm{m} l$ of the soybean oil fatty acids was mixed 0.5 $\mathrm{m} l$ of chloroform solution containing $2.0 \mathrm{mg} / \mathrm{ml}$ of the pheophorbide a, and irradiated under light intensity of 20,000 lux. Control system contianed $0.5 \mathrm{~m} l$ of chloroform instead $0.5 \mathrm{~m} l$ chloroform solution of pheophorbide a.

(A) control, irradiation time was $0 \mathrm{hr}$, (B) control, irradiation time was $3 \mathrm{hr}$, (C) control, irradiation time was $5 \mathrm{hr}$, (D) with pheophorbide a, irradiation time was $3 \mathrm{hr}$, (E) with pheophorbide a, irradiation time was $5 \mathrm{hr}$.

$1=\mathrm{C}_{16: 0}, 2=\mathrm{C}_{18: 0}, 3=\mathrm{C}_{18: 1}, 4=\mathrm{C}_{18: 2}, 5=\mathrm{C}_{18: 3}$.

光を照射してもガスクロマトグラム上に変化はみられな い。

これらの結果，すでに光增感作用を有するといわれて いるローズベンガルについてリノール酸の光分解能を検 討した結果, 分解能はみられない。フェオホーバイド $\mathrm{a}$ はいずれの実験材料についても光の存在によって $\mathrm{C}_{18: 1}$, $\mathrm{C}_{18: 2}, \mathrm{C}_{18: 3}$ 等の二重結合を有する不飽和脂肪酸の分解能 がみられた。これらの機構については明らかではない が,フェオホーバイド aが光ェネルギーを吸収し, 励起 状態となり，そのエネルギーが二重結合を有する脂肪酸 に特異的に作用し, 不飽和脂肪酸の分解が起こるものと 考えられるので,ささらに今後その機構について検討した い。

フェオホーパイドaの投与によって起こる白ネズミの 光過敏症 (死亡) と不飽和脂肪酸の光分解との関係, 寸 なわち，生体内反応と試験管内反応とを同一視して論ず ることは問題であるが, Clare ${ }^{13)}$ が光力学的物質の投与 と光照射によって生体中のたん白質（それを構成する特 定のアミノ酸）の分解によって光過敏症が起こると述へ ていることから, 生体内脂肪酸がフェオホーバイド a と 光の存在によって分解が起こり体内にその分解産物が生
成されることも考えられる。また自動酸化油の毒性につ いても多くの報告がみられ，そのらちでも過酸化物の分 解物による毒性は著しく, 投与後数時間で死亡するこ そ 14)15)などから，フェオホーバイド a 投与と光照射によ って起こる光過敏症と脂肪酸の光分解との関連性につい て今後さらに検討を要する。

\section{要約}

タカ菜漬より分離したフェオホーバイド a の光力学的 作用の機構を明らかにするため, ローズペンガルと対比 して白ネズ ミの光過敏症, アミノ酸, 脂肪酸の光分解等 について検討した。

1）フェオホーバイド、を白ネズミに投与し光を照射 すると強い致死効果がみられたが，ローズペンガルを投 与した白ネズミは光照射後 1 週間目に脱毛, 皮虐の壊死 等の後遗症がみられた。

2）アミノ酸溶液（トリプトフォン，システインを除 く 17 種のアミノ酸) にローズベンガルを添加し, 光照 射すると，ヒスチジン，メチオニン，シスチン，チロシ ンの分解がみられるが, フェオホーパイドではいずれ のアミノ酸も分解されなかった。 

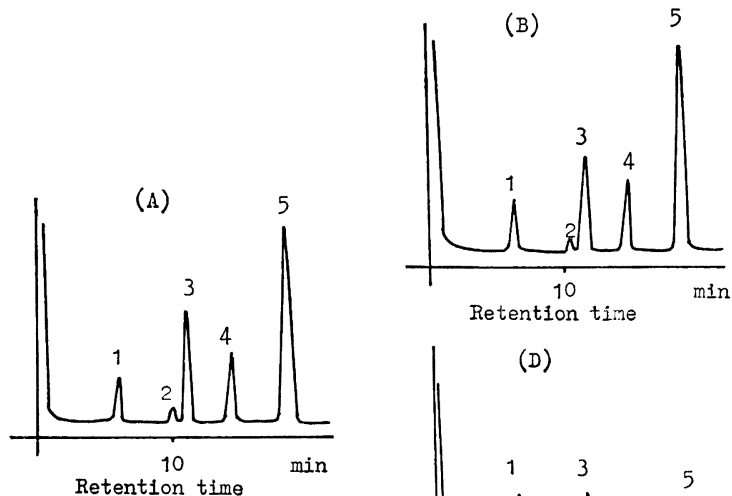

(D)

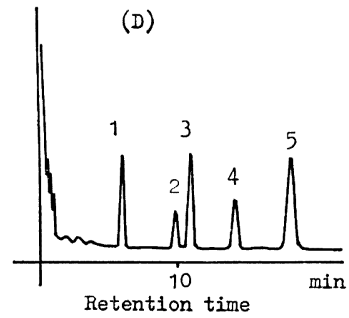

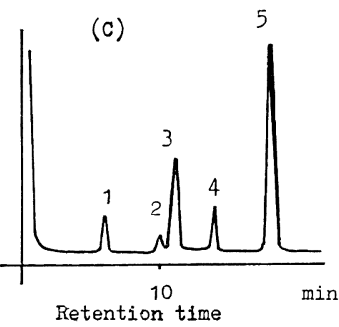

$(E)$

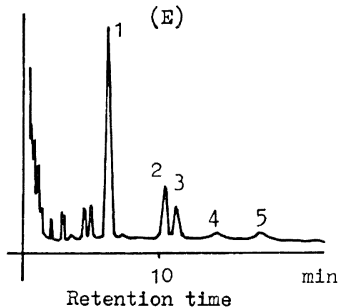

Fig. 5. Changes in the gas chromatograms of linseed oil fatty acids produced by the photodynamic action of pheophorbide a.

$9.5 \mathrm{~m} l$ of chloroform solution containing $2.0 \mathrm{mg} / \mathrm{m} l$ of the linseed oil fatty acids was mixed $0.5 \mathrm{~m} l$ of chloroform solution containing $2.0 \mathrm{mg} / \mathrm{ml}$ of the pheophorbide a, and irradiated under light intensity of 20,000 lux. Control system contained $0.5 \mathrm{~m} l$ of chloroform instead $0.5 \mathrm{~m} l$ chloroform solution of pheophorbide a.

(A) control, irradiation time was $0 \mathrm{hr}$, (B) control, irradiation time was $3 \mathrm{hr}$, (C) control, irradiation time was $5 \mathrm{hr}$, (D) with pheophorbide a, irradiation time was $3 \mathrm{hr}$, (E) with pheophorbide a, irradiation time was $5 \mathrm{hr}$.

$1=\mathrm{C}_{16: 0}, 2=\mathrm{C}_{18: 1}, 3=\mathrm{C}_{18: 1}, 4=\mathrm{C}_{18: 2}, 5=\mathrm{C}_{18: 3}$.

3）脂肪酸にフェオホーバイド $\mathrm{a}$ を加え，光を照射す ると不飽和脂肪酸であるリノレン酸 $\left(\mathrm{C}_{18: 3}\right)$, リノール 酸 $\left(\mathrm{C}_{18: 2}\right)$, オレイン酸 $\left(\mathrm{C}_{18: 1}\right)$ の分解がみられた。しか し，ローズベンガルによるこれら脂肪酸の分解はみられ なかった。

\section{文献}

1）山田幸二, 中村延生蔵 : 栄盖と食糧, 25, 466 (1972)

2）黑田嘉一郎, 吉川春寿, 中尾喜久, 脇坂行一： 血液化学, 228 (1968), 朝倉書店, 東京

3）山田幸二：日本栄養食糧学会東北支部大会講演 要旨 (1972)

4）稲田邦子, 宮沢文雄 : 食街誌, 10,344 (1969)

5）稻田邦子, 宮沢文雄, 谷村顕雄 : 食衛誌, 11, 238 (1970)
6）村上浩紀, 坂田幸平, 波多野昌二, 渡辺忠雄 : 食衛誌, 13，12 (1972)

7）村上浩紀, 坂田幸平, 波多野昌二, 渡辺忠雄 : 食衛誌，13，19 (1972)

8) Weil, L., Seibles, T.S. and Herskovits, T.T. Arch. Biochem. Biophys. 111, 308 (1965)

9) Bellin, J.S. and Yankus, C.A.: Arch. Biochem. Biophys., 123, 18 (1968)

10）松浦輝雄, 野崎一編：化学の領域 增刊 93 有 機光化学, 263 (1970), 南江堂, 東京

11) Holt, A.S. and Jacobs, E.E.: Am. J. Botany, 41, 701 (1954)

12）橋本芳郎, 堤 淳二 : 食衛誌, 4. 185 (1963)

13) Clare, N.T.: Advance in Vet. Sci., 2, 181 (1955)

14）吉岡倭子, 金田尚志: 油化学, 21, 316 (1972)

15）天野立爾：食衛誌，13，293 (1972)

(昭和 49 年 3 月 11 日受理) 